\section{Welcome Message for Journal of Experimental Food Chemistry}

\section{Feyzullah Tokay}

Department of Chemistry, Balikesir University Science and Arts, 10145 Cagis, Balıkesir, Turkey

*Corresponding author: Department of Chemistry, Balikesir University Science and Arts, 10145 Cagis, Balıkesir, Turkey, Tel: +90543 4154794 ; E-mail: feyzullahtokay@balikesir.edu.tr

Received date: Sep 10, 2015; Accepted date: Sep 20, 2015; Published date: Sep 25, 2015

Copyright: (C) 2015 Tokay $\mathrm{F}$ et al. This is an open-access article distributed under the terms of the Creative Commons Attribution License, which permits unrestricted use, distribution, and reproduction in any medium, provided the original author and source are credited.

\section{Editorial}

I am delighted to welcome you to our new, peer-reviewed and open access journal, Journal of Experimental Food Chemistry (JEFC). This publication has been created with expert knowledge and an international collaboration. I appreciate the work of all of the authors, reviewers and contributing staff who have supported the journal.

JEFC offers speedy publication of high quality researches related to food chemistry. The journal propose an extremely wide thematic scope including Food Chemistry, Food Standards, Food Hydrocolloids, Food Irradiation, Analytical Techniques in Food Safety, Food Analytical Chemistry, Food Chemistry and Toxicology, Physical Chemistry of Food, Food Organic Chemistry, Food Analysis, Food Supplements,
Hazard Analysis \& Critical Control Points (HACCP), Food science, Components of food, Food processing, Food Technology, Food contaminants, Food proteins, Food Enzymes, Food Vitamins, Food Minerals, Food Colouring, Dietary supplements, Food fortification, Food preservation, Food Chemical reactions and Food Chemicals codex.

We welcome original researches, reviews and critical commentaries and also welcome any comments or suggestions to improve our journal.

I hope, you will consider JEFC to publish your researches and we look forward to welcoming your submissions. 